\title{
Birds Communities at Mangrove of Batu Ampar, Kubu Raya District, West Kalimantan Province
}

\author{
Jarwadi Budi Hernowo \\ Departement of Forest Resource Conservation and Ecotourism, Faculty of Forestry, Bogor Agricultural University, \\ Academic Ring Road, Dramaga, Campus, Bogor Indonesia, 16680
}

Received April 20, 2016/ Accepted August 25, 2016

\begin{abstract}
Batu Ampar mangrove is an important bird habitat especially for birds which have relation to mangrove ecosystem in West Kalimantan. The research was conducted in February to March 2007, at mangrove Batu Ampar demo site. Sampling was done to get representative area for bird survey. The 19 transects were chosen as sampling site to collect bird data such as species and number of individual. Bird surveys were carried out using Reconnaissance method and IPA (Index Point of Abundance) count method. The length of each transect was approximately $500 \mathrm{~m}$. The results showed that the bird community's structure dominated by insectivorous birds represented approximately $60 \%$ of total bird's species at mangrove Batu Ampar demo site. The abundance numbers of the individual with the bird's species has relation pattern like J opposite. Percentage of dominant bird species was approximately $11 \%$, those are such as stork billed kingfisher, white-collared kingfisher, common iora, chestnuts-rumped babbler, Strip-Tit Babbler, magpie robin, ashy tailorbird, mangrove blue flycatcher, pied fantail, mangrove whistler, Brown-throated Sunbird and Cooper-Throated Sunbird. Vertical structure of mangrove vegetation was used by birds at mangrove Batu Ampar demo site is mainly B stratum, and it used around $60 \%$ birds species. Based on dendrogram analysis there were 5 cluster birds species. The mangrove bird specialists found at sampling area were mangrove blue flycatcher and Cooper throated sunbird.
\end{abstract}

Keywords: Birds communities, mangrove, Batu Ampar, West Kalimantan

*Correspondenceauthor,email:jblina11@yahoo.com,phonelfax:+62-8121102534

\section{Introduction}

Mangrove Batu Ampar covers an area of approximately 14.050 ha and it is one of Kapuas River estuarine ecosystem. Batu Ampar mangrove is natural mangrove which it occurs at Kubu Raya district formerly was Pontianak District, West Kalimantan province. The mangrove is a unique ecosystem and fragile, it presents both ecosystem terrestrial and brackish water. But the mangrove has an important function on such as nursery ground, spawning ground, and habitat of wildlife include the bird.

Besides for bird's habitat, mangrove Batu Ampar has the social and economical function for people who live surrounding the area. Local people used mangrove for many purposes such as chips, charcoal, and for fish pond. If the mangroves are not well managed, it will cause a decrease both in the quality and quantity of mangrove as well as the bird's habitat.

Few studies on mangrove birds have been done in Indonesia, Malaysia, and Singapore (e.g. McClure \& Husain 1968; Nisbet 1968; van Balen 1989; Noske 1995; Elfidasari 2006). Up to now there are still lacks of data on mangrove biodiversity, especially which emphasize bird diversity. Meanwhile, mangrove Batu Ampar as one of mangrove demo site in Indonesia. The conservation management of the demo site need basic information like birds diversity must be collected soon by guided research.

The objective of study aimed at obtaining data and information on bird diversity and habitat used by bird species concerning composition and structure of mangrove vegetation.

\section{Methods}

Study Site The geographical position of mangrove Batu Ampar demo site is $\mathrm{S}^{\circ} 20^{\prime} 53,14^{\prime \prime}-0^{\circ} 58^{\prime} 58,23^{\prime \prime}$ and E109 $06^{\prime} 1,64^{\prime \prime}-109^{\circ} 53^{\prime} 31,23$ ", Southern part of Kubu Raya (Pontianak previously) District, West Kalimantan Province. Topographic of the project area is flat, but at several places occur hilly area such as Bukit Radak, Bukit Batu Ampar, and Bukit Bongkok.

The demo site area is estuarine of Kapuas River. There are many streams that originate on the low hills and drain the project area to the nearby Batu Ampar bay. Besides Kapuas river, several river flows be caused many delta presents at the area such as Keluang river, Kemuning, Sepada, Bunbun dan Seruat river. The drainage patterns perform dendrite flow and it unique with the delta. 
The climate at the project area is tropical with unclear a distinct between dry season and wet season, but less precipitation between June and July (Figure 1). The total average annual rainfall is $3,887 \mathrm{~mm}$, the average temperature is $28.5^{\circ} \mathrm{C}$ and The average humidity around $89 \%$.

Sediment alluvial soil covered almost dominated at the demo site project area. Physically, the solum is quite deep, and the chemist character is fertile. The mangrove dominated by tumu (Bruguiera gymnorhiza), bakau (Rhizophora apiculata,), and nipah (Nypha fruticans).

The research was conducted around one month from 25 February to 24 March 2007, at mangrove Batu Ampar demo site. Sampling was done to get representative area for bird survey. The 19 transects were chosen as sampling site for collect bird data such as species and individual number. The transect sample plot was select such as Sungai Kemuning
Hilir, Kemuning Hulu, Pulau Panjang 4, Pulau Panjang 3, Sungai Keluang, Selat Perling, Teluk Air, Sungai Sempadan Kiri, Sungai Sempadan Kanan, Gunung Terjun, Gunung Radak, Ekotone Gunung Terjun, Nipah Panjang, Sungai Bun-Bun, Pulau Burung, Selat Sheh, Sungai Seruat, Pulau Tiga, Pulau Dabung and Batu Ampar. Sampling site which were chosen can be seen at (Figure 1).

Observation Procedure Birds surveys were used Reconnaissance method and IPA(Index Point of Abundance) count method. Nineteen transects were made as mentioned above, with the length of each transect around $500 \mathrm{~m}$. Data collections started every morning at 07.00 a.m. and lasted until 09.00 a.m. The counting of individual numbers was based on direct visual contact or the bird calls. The shape of sample for IPA method can be seen in Figure 2.

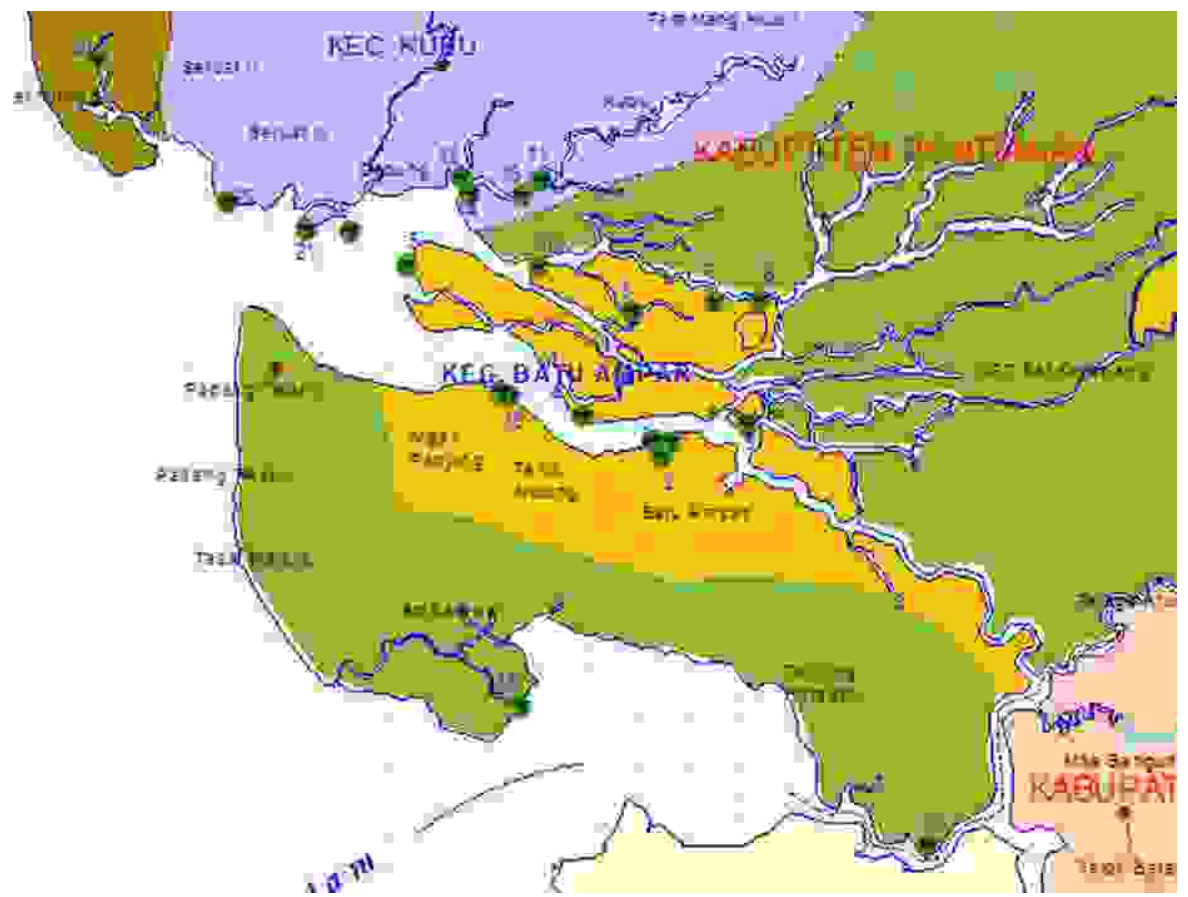

Figure 1 Sampling site at demo site mangrove Batu Ampar.

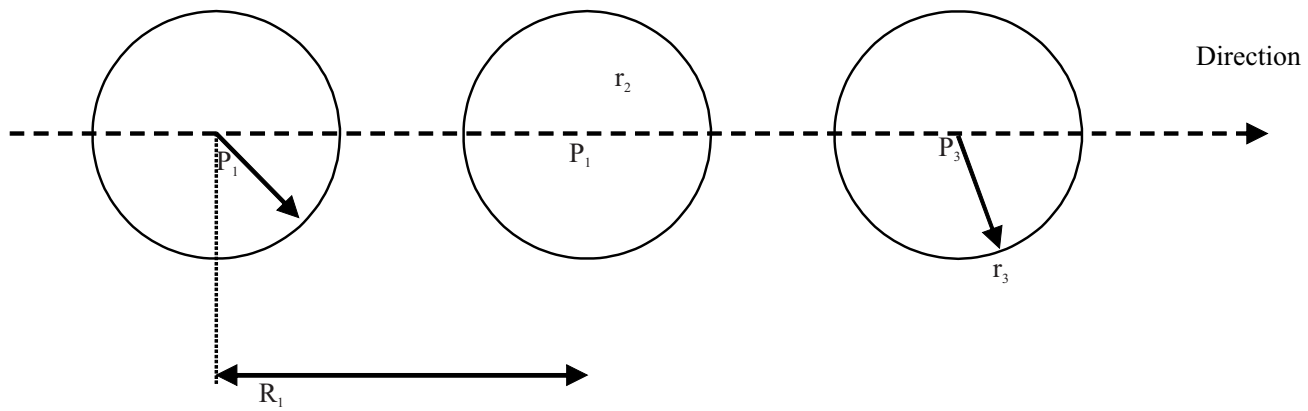

Figure 2 Shape of transect of IPA method. Point centre $(\mathrm{P})$, radius distance $(\mathrm{R})$. 


\section{Data Analysis}

1.1 Species Diversity Index The Shannon index (Magurran 1988) describes bird species diversity a different long transects

\section{$\mathbf{H}=\boldsymbol{- \Sigma} \mathbf{P}_{\mathrm{i}} \ln \mathbf{P}_{\mathrm{i}}$}

$\mathrm{P}_{\mathrm{i}}$ is the number of individuals of species divided by the total number of individuals. Species diversity influenced of species richness (number of species in the sample) and evenness or equitability). The following formula such as: $\mathbf{E}=\mathbf{H} / \mathbf{H}_{\text {max }}$

$\mathrm{H}_{\max }=-\log 1 / \mathrm{n},(\mathrm{n}=$ number of species in the sample $)$.

1.2 Similarity indices The Jaccard similarity index (S) (in Mueller-Dombois \& Ellenberg 1974) index shows the changes or similarity in species composition among different samples (i.e., along the different transects):

$\mathbf{S}=\mathbf{c} / \mathbf{a}+\mathbf{b}+\mathbf{c}$

$\mathrm{a}$ and $\mathrm{b}$ are numbers of species unique to samples 1 and 2 respectively, and $\mathrm{c}$ is species common to both. The dendrogram was used to analyze clustering bird's community in each habitat at the sampling site. Minitab SPSS 14 was used to help the process of clustering analysis. This technique describes how the relation between birds community at each sample plot based on similarity index.

Dominated by birds species at sample plot were count the formula,

$\mathbf{D i}=\mathbf{K r}+\mathbf{F r}$

Di $=$ Domination index

$\mathrm{Kr}=$ Relative Density

$\mathrm{Fr}=$ Relative Frequency

The criteria of dominant species if value of

Di $>5 \%$ is dominant species

Di $=2 \%-5 \%$ moderate

Di $<$ rare species

\section{Results and Discussion}

Bird Species Richness Based on field observation there were 57 species of birds at mangrove Batu Ampar demo site. The species richness was classified as medium (Adil et al. 2010, Elfidasari 2006, Jumilawaty 2011, Mardiastuti 1992, Mustari 1992, Widodo et. al. 1996). The birds attribute were found 2 species of bird is mangrove specialist, 4 species are birds migratory, 2 species waders, 1 species migratory raptor. Meanwhile, 15 species protected birds in Indonesia were found used mangrove as their habitat. The total number of bird species found at the demo site area was recorded in Table 1. The higher number of bird species is at mangrove primer habitat. The number bird species have influenced by mangrove vegetation such as composition and strata of mangrove canopy and mudflat area (Adil et al. 2010, Elfidasari 2006, Jumilawaty 2011, Baker et al. 2002, Lambert \& Collar 2002, Lane et all 2011, Nisbet 1968, Noske 1995, Noske 1996. Sodhi et al. 1997, van Balen 1989, Widodo et al. 1996).

The mangrove specialist present at mangrove Batu Ampar demo site were Cooper-Throated Sunbird (Nectarinia calcostetha) and mangrove blue flycatcher (Cyornis rufigastra). According to Noske (1995), that mangrove blue flycatcher is mangrove specialist bird. Migratory terrestrial species present at the demo site area were oriental-honey buzzard (Pernis ptilororhynchos), barn swallow (Hirundo rustica), blue rock thrush (Monticola solitarius), horsfield's bronze cuckoo (Chrysococcyx basalis) and asian brown flycatcher (Muscicapa daurica), but 2 species of waders were common sandpiper (Tringa hypoleucos) and whiskered tern (Chlidonias hybridus).

According to the Indonesian Government Regulation (PP No 7 tahun 1999), the protected birds occurred at sampling site were great egret (Egretta alba), lesser adjutant (Leptoptilos javanicus), osprey (Pandion haliaetus), oriental honey buzzard (P. ptilorhynchos), brahminy kite (Haliastur indus), white bellied fish-eagle (Haliaeetus leucogaster), grey-headed fish-eagle (Icthyophaga icthyaetus), changeable haw-eagle (Spizaetus cirrhatus) black backed kingfisher (Ceyx erithacus), rufous backed kingfisher (Ceyx rufidorsus), stork billed kingfisher (Pelargopsis capensis) white collared kingfisher (Halcyon chloris), ruddy kingfisher (Halcyon coromanda), pied fantail (Rhipidura javanica), cooper throated sunbird ( $N$. calcostetha), and brown throated sunbird (Anthreptes malacensis).

Structure of Bird CommunityThe structure of bird communities at mangrove Batu Ampar demo site can be seen from the trophic level or bird guild. The bird guild at the project area is recorded in Table 2. The dominant guild at sample plot was insectivore approximately $60 \%$ of bird

Table 1 Species birds richness at mangrove Batu Ampar demo site

\begin{tabular}{llllclc}
\hline Species & $\begin{array}{l}\text { Mangrove } \\
\text { Primer } \\
\text { (species) }\end{array}$ & $\begin{array}{l}\text { Mangrove Log-over } \\
\text { Area (species) }\end{array}$ & $\begin{array}{l}\text { Ecotone } \\
\text { mangrove } \\
\text { (species) }\end{array}$ & $\begin{array}{l}\text { Protected } \\
\text { (species) }\end{array}$ & $\begin{array}{l}\text { Mangrove } \\
\text { Specialis } \\
\text { (species) }\end{array}$ \\
\hline Birds & 34 & $11-22$ & 13 & 16 & 3 \\
(species)
\end{tabular}

Table 2 The bird guild at Batu Ampar mangrove demo site

\begin{tabular}{lcc}
\hline Guild & Number of species & Percentage (\%) \\
\hline Carnivores & 7 & 10.94 \\
Fischivores & 14 & 21.88 \\
Mollusk and arthropod feeder & 2 & 3.12 \\
Insectivores & 34 & 53.13 \\
Frugivores & 5 & 7.81 \\
Nectarivores & 2 & 3.12 \\
\hline
\end{tabular}


community at mangrove ecosystem. This phenomenon was similar to some observations at other mangrove ecosystems that insectivore's bird was dominant (Adil et al. 2010, Elfidasari 2006, Jumilawaty 2011, Mustari 1992, Nisbet 1968, Noske 1995, Sodhi et al. 1997). Van Balen (1989) also mentioned that the mangrove in Java of insectivores and nectarivores birds was dominant. The smallest number species at the mangrove is mollusk \& anthropod feeder and nectarivores bird around $2 \%$ of bird community.

Birds Diversity and Evenness The bird species diversity at the mangrove project area classified as moderate. The value of Shannon-Wiener Index Diversity was 1.68-2.91. Meanwhile, the evenness index bids species is $0.83-0.96$. The highest diversity index was at Selat She sample plot and the smallest was at Sungai Kemuning Hulu. The species diversity and evenness classified as moderate (Adil et al. 2010, Elfidasari 2006, Jumilawaty 2011; Mustari 1992). According to Hernowo (2005), the factors have influenced to bird species diversity in the forest which was high variation species vegetation, the number of forest layer and least disturbed areas.

Abundance and local distribution The relation between species and the individual number of the bird at mangrove Batu Ampar demo site is J pattern reverse (Figure 4). This phenomenon is common in tropical rain forest area. Only five species are as abundance bird ( $>50$ individuals) i.e brown-throated sunbird (A. malacensis), common iora (Aegithina tiphia), cooper throated sunbird (N. calcostetha), mangrove blue flycatcher (C. rufigastra) and ashy tailorbird (Orthotomus ruficeps). Besides those birds are abundance species, they are also having local distribution spread all of the sample area. Noske (1995) mentioned that ashy tailorbird was the most abundant species at each of the census sites in mangrove Peninsula of Malaysia.

Meanwhile, birds species which have abundance are moderate (50 ind $>\mathrm{D}>20$ ind) such as magpie robin
(Copsychus saularis), pied fantail ( $R$. javanica), white collared kingfisher (H. chloris), chestnuts rumped babbler (Stachyris maculata) and mangrove whistler (Pachycephala grisola). The remaining bird species in the Figure 4, are as considered rare.

Dominant bird There are 12 birds species classified as dominant birds at mangrove Batu Ampar demo site (Di $>5$ $\%)$, such as stork billed kingfisher ( $P$. capensis), white collared kingfisher (H. chloris), common iora (A. tiphia), chestnuts rumped babbler ( $S$. maculata), strip tit babbler (Macronous gularis), magpie robin (C. saularis), ashy tailorbird (O. ruficeps), mangrove blue flycatcher ( $C$. rufigastra), pied fantail ( $R$. javanica), mangrove whistler $(P$. grisola), brown throated sunbird (A. malacensis) and cooper throated sunbird (N. calcostetha).

Similarity of Bird Communities at Batu Ampar Mangrove Demo Site Based on dendrogram analysis (Figure 5), there are 5 group clusters birds communities at mangrove Batu Ampar demo site. The first cluster is groups species of birds present at mangrove of Sungai Kemuning hilir, Teluk Air, Pulau Dabung, Sungai Kemuning hulu, Sungai keluang and Ecotone Gunung Terjun with similarity index approximately $75 \%$, but second cluster is occur at mangrove of Selat Perling, Pulau tiga, Sungai Sepadan kiri, and Gunung Radak of $78 \%$.

Meanwhile the third cluster bird communities is birds occur at mangrove of Pulau Panjang 4, Pulau Panjang 2, and Gunung Terjun of $80 \%$ and the fourth cluster is bird communities which live at mangrove of Nypah Panjang, Selat Sheh, and Bun-bun of $70 \%$ similarity index, but the fifth cluster is birds communities present at mangrove of Pulau Burung, and Sungai Seruat approximately $65 \%$.

Mangrove strata used by Bird Communities Based on field observation the mangrove habitat can be divided into three layer strata such as stratum A is mangrove habitat at

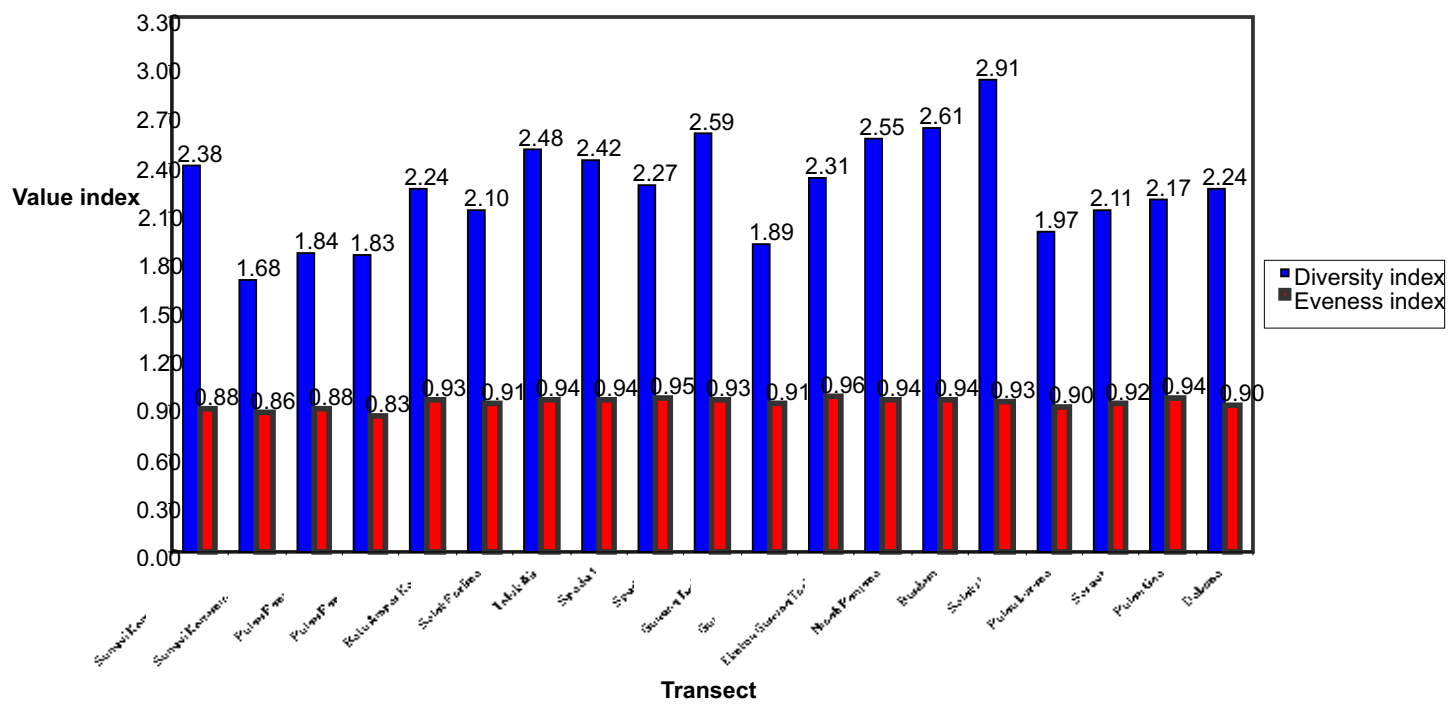

Figure 3 Chart diagram of birds species diversity and evenness at Batu Ampar mangrove demo site. 


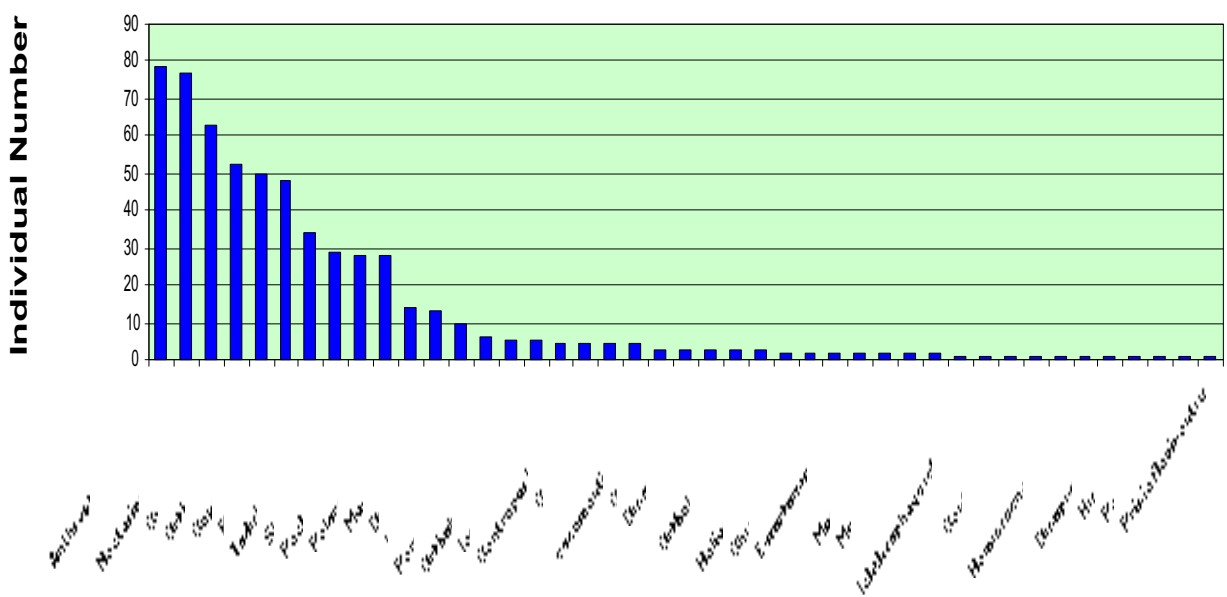

Birds Species

Figure 4 Chart diagram of relation between individual number and birds species at mangrove Batu Ampar demo site.

Tabel 3 Birds domination index at mangrove Batu Ampar demo site

\begin{tabular}{|c|c|c|c|}
\hline Birds species & Common name & Individu al Number & Di (\%) \\
\hline Pelargopsis capensis & Stork billed Kingfisher & 14 & 6.32 \\
\hline Halcyon chloris & White collared Kingfisher & 29 & 8.40 \\
\hline Aegithina tiphia & Common Iora & 77 & 20.43 \\
\hline Stachyris maculata & Chestnuts rumped Babbler & 28 & 10.87 \\
\hline Macronous gularis & St rip tit Babbler & 13 & 5.71 \\
\hline Copsychus saularis & Magpie Robin & 48 & 15.12 \\
\hline Orthotomus rufisep & Ashy Tailorbird & 50 & 15.45 \\
\hline Cyornis rufigastra & Mangrove blue Flycatcher & 52 & 16.67 \\
\hline Rhipidu rajavanica & Pied Fantail & 34 & 11.88 \\
\hline Pachycephala grisola & Mangrove Whistler & 28 & 11.31 \\
\hline Anthreptes malacensis & Brown throated Sunbird & 79 & 20.33 \\
\hline Nectarinia calcostetha & Cooper throated Sunbird & 63 & 17.64 \\
\hline
\end{tabular}

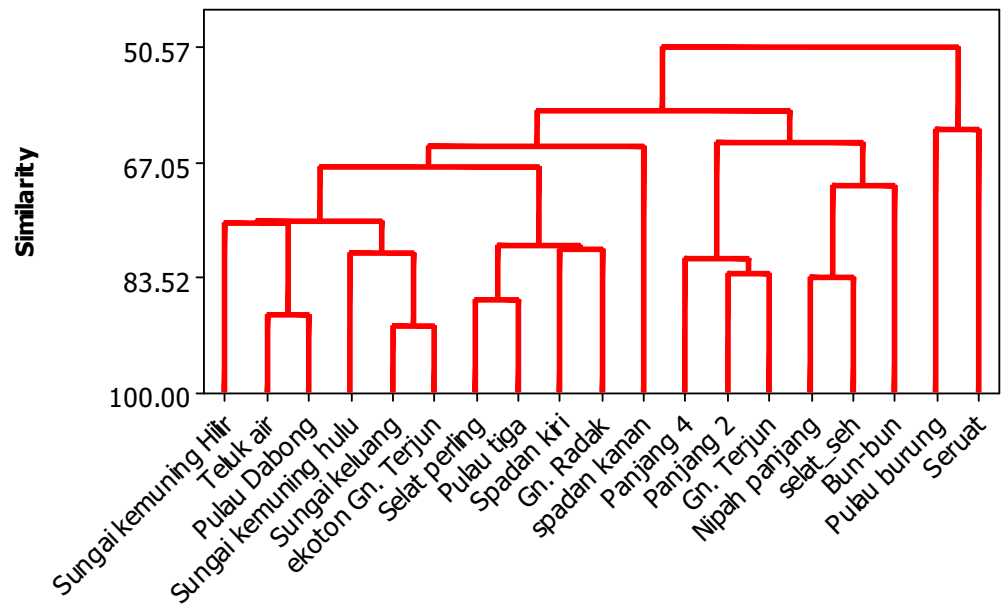

Variables

Figure 5 Dendrogram of bird communities at mangrove Batu Ampar demo site. 
space up $10 \mathrm{~m}$ high, but B stratum is mangrove habitat at spaced $5-10 \mathrm{~m}$ and stratum $\mathrm{C}$ at space below $5 \mathrm{~m}$ until forest floor. The results showed that stratum $B$ is preferred by many bird species. The strata used were rather similar with Noske's observation (Noske 1995) that the bird foraging high at mangrove in Malaysia was significant used high at 2-8 $\mathrm{m}$. Several examples of vertical habitat space was used by birds were reported as bellow.

The B mangrove stratum at ecotone between mangrove and lowland tropical rain forest was used at approximately 60 $\%$ of birds. The bird species used vertical habitat space was ashy tailorbird (O. ruficeps), mangrove blue flycatcher $(C$. rufigastra), magpie robin (C saularis), stork billed kingfisher $(P$ capensis $)$, pied fantail $(R$ javanica $)$ and lesser coucal (Centropus bengalensis) (Figure 6).

Several birds used the mangrove and mudflat areas, but of $60 \%$ those birds used B stratum. They were common iora $(A$ tiphia), mangrove blue flycatcher (C. rufigastra), brown throated sunbird (A. malacensis), magpie robin ( $C$ saularis), Stork-billed kingfisher ( $P$ capensis), white collared kingfisher (H chloris) and pied fantail ( $R$ javanica) (Figure 7).

Mangrove in good condition, stratum B was used by $50 \%$ birds species. The species of birds used the storey such as common iora (A tiphia), ashy tailorbird (O. ruficeps), mangrove blue flycatcher ( $C$. rufigastra), cooper throated sunbird ( $N$ calcostheta), olive-backed woodpecker (Dinopium rafflesii), magpie robin (C. saularis), brahminy kite (H. indus), black backed kingfisher (C. erythacus), rufous backed kingfisher ( $C$. rufidorsus), stork billed kingfisher ( $P$ capensis), mangrove whistler ( $P$ grisola $)$, chestnuts rumped babbler ( $S$ maculata), strip tit babbler $(M$ gularis) and rufous tailed tailordbird (Orthotomus sericeus). However, at A and C stratum were used $25 \%$ of species birds (Figure 8).

Mangrove logged over forest is condition space of wood density, strata B still be used by $60 \%$ birds species (Figure 9). The bird's species used such as common iora, ashy tailordbird, mangrove whistler, pied fantail, chestnut rumped babbler and sitta nutchad.

The mudflat area which is growth mangrove vegetation, B stratum was used birds around $80 \%$ species such as common iora, mangrove blue flycatcher, cooper throated sunbird, magpie robin, mangrove whistler, ashy tailordbird, pied fantail, rufous backed kingfisher, and ruddy kingfisher (Figure 10).

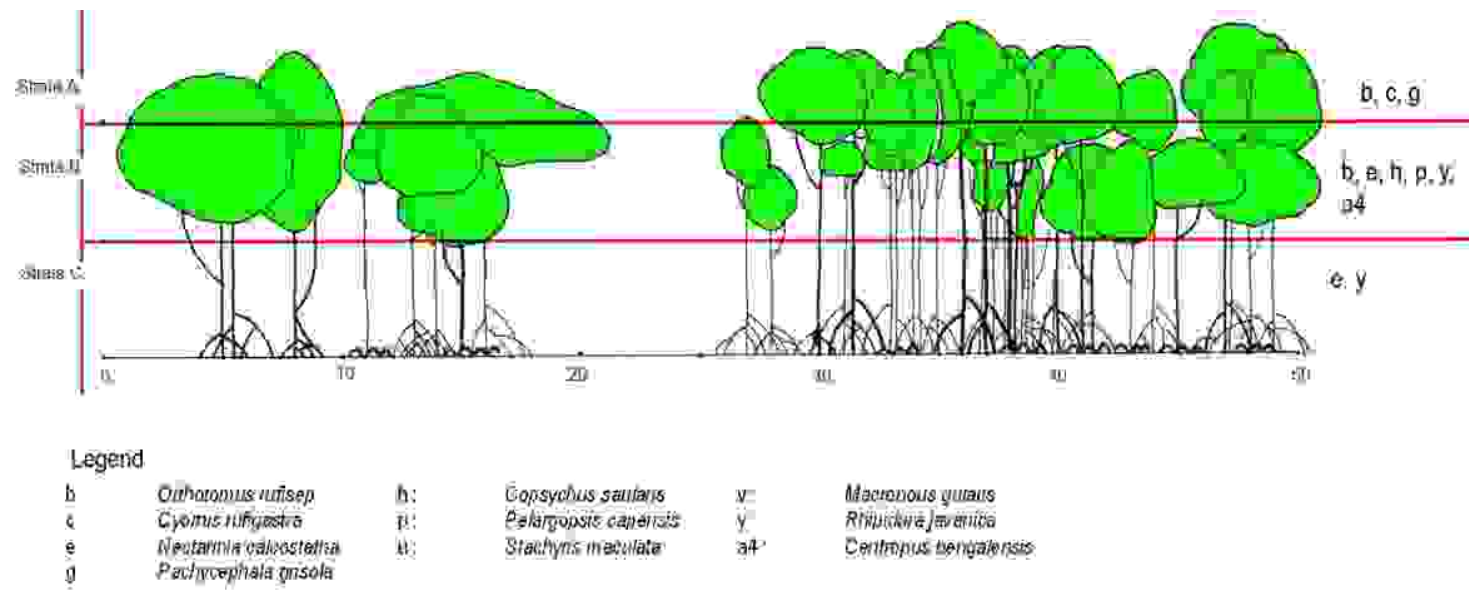

Figure 6 Mangrove strata was used by birds at ecotone between mangrove and lowland tropical rain forest.
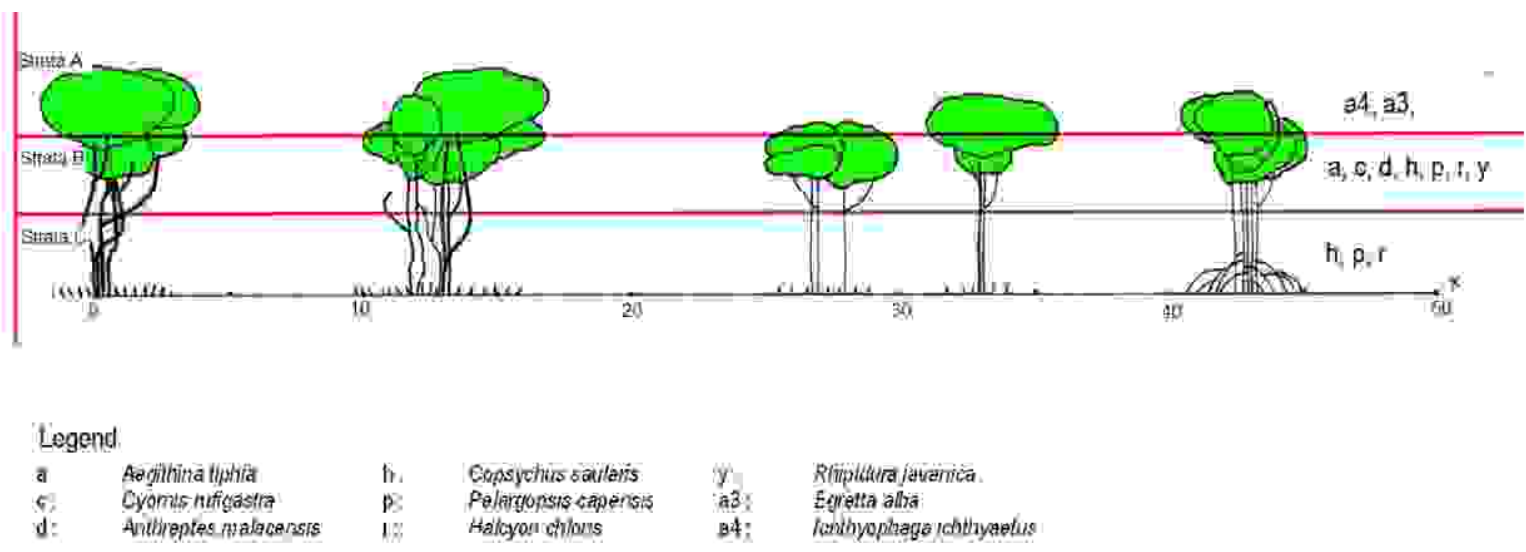

Figure 7 Mangrove strata was used by birds at shore area where present madflat area. 

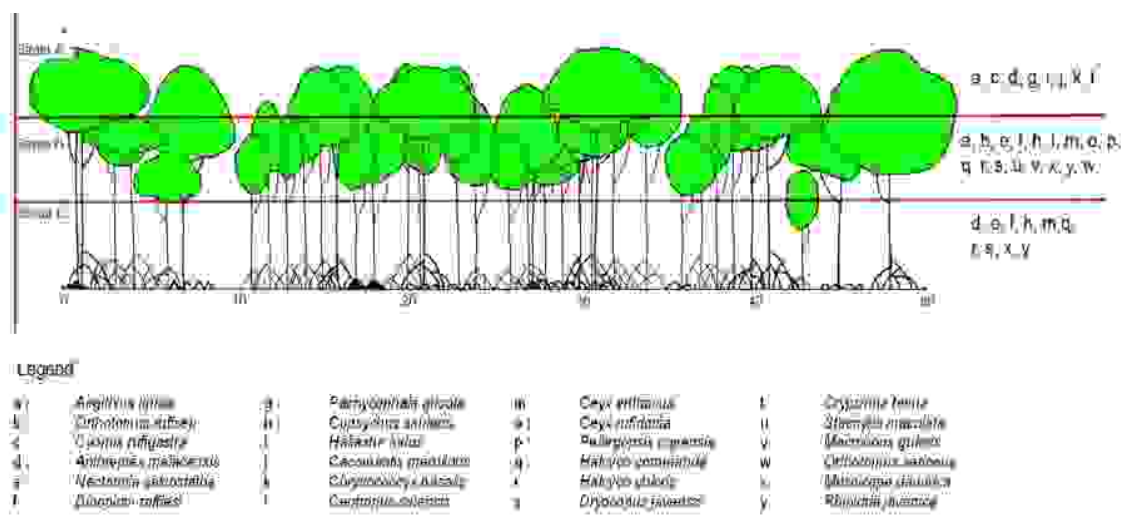

Figure 8 Mangrove strata was used by birds at good forest condition.

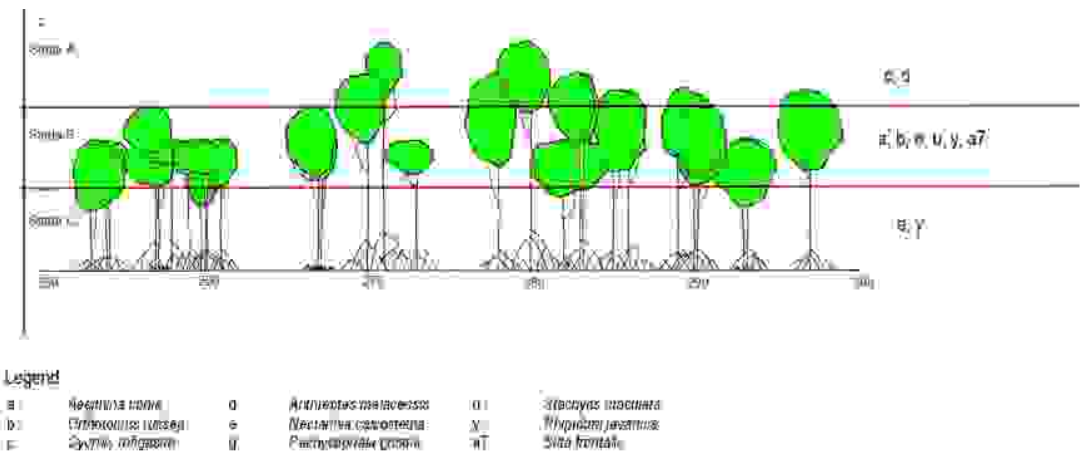

Figure 9 Mangrove strata was used by birds at logged over forest with space condition.

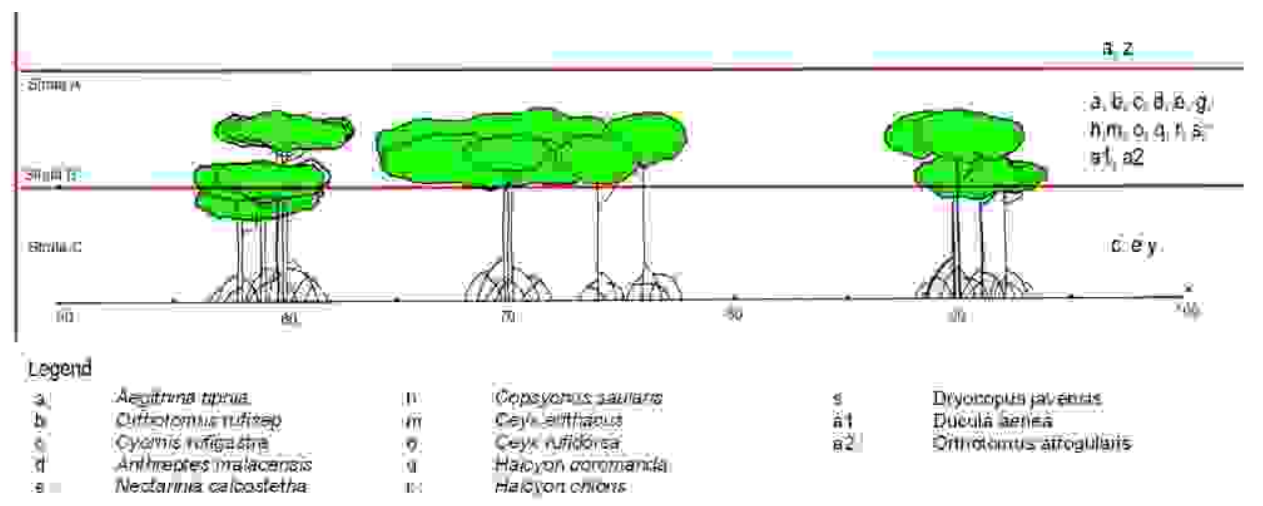

Figure 10 Mangrove strata was used by birds at mudflat area.

\section{Conclusion}

Mangrove Batu Ampar demo site has moderate bird diversity $(\mathrm{H}=1.68-2.91)$ and the evenness $(\mathrm{E}=83-0.96)$. Fifty-seven (57) species of birds have been identified occur at the mangrove area, including two species of mangrove specialist i.e, mangrove blue flycatcher and cooper throated sunbird present. The bird community structure based on guild analysis showed that insectivorous birds represented approximately $60 \%$ of total bird species at mangrove Batu Ampar demo site and the number of species was around $13 \%$ from total bird species occurred at project area. The abundance between numbers of individual with the birds species have relation pattern like $\mathrm{J}$ opposite. The percentage of dominant bird species was around $11 \%$, those are such as stork billed kingfisher ( $P$. capensis), white collared kingfisher (H. chloris), common iora (A. tiphia), chestnuts rumped babbler ( $S$. maculata), strip tit babbler (Macronous gularis), magpie robin (C. saularis), ashy tailorbird (O. ruficeps), mangrove blue flycatcher (C. rufigastra), pied fantail ( $R$. javanica), mangrove whistler ( $P$. grisola), brown throated sunbird (A. malacensis) and cooper throated sunbird (N. calcostetha). Vertical structure of mangrove vegetation was used by birds at mangrove Batu Ampar demo site mantly is B stratum, and it be used around $60 \%$ birds species. Base on dendrogram analysis occur 5 cluster birds species. 


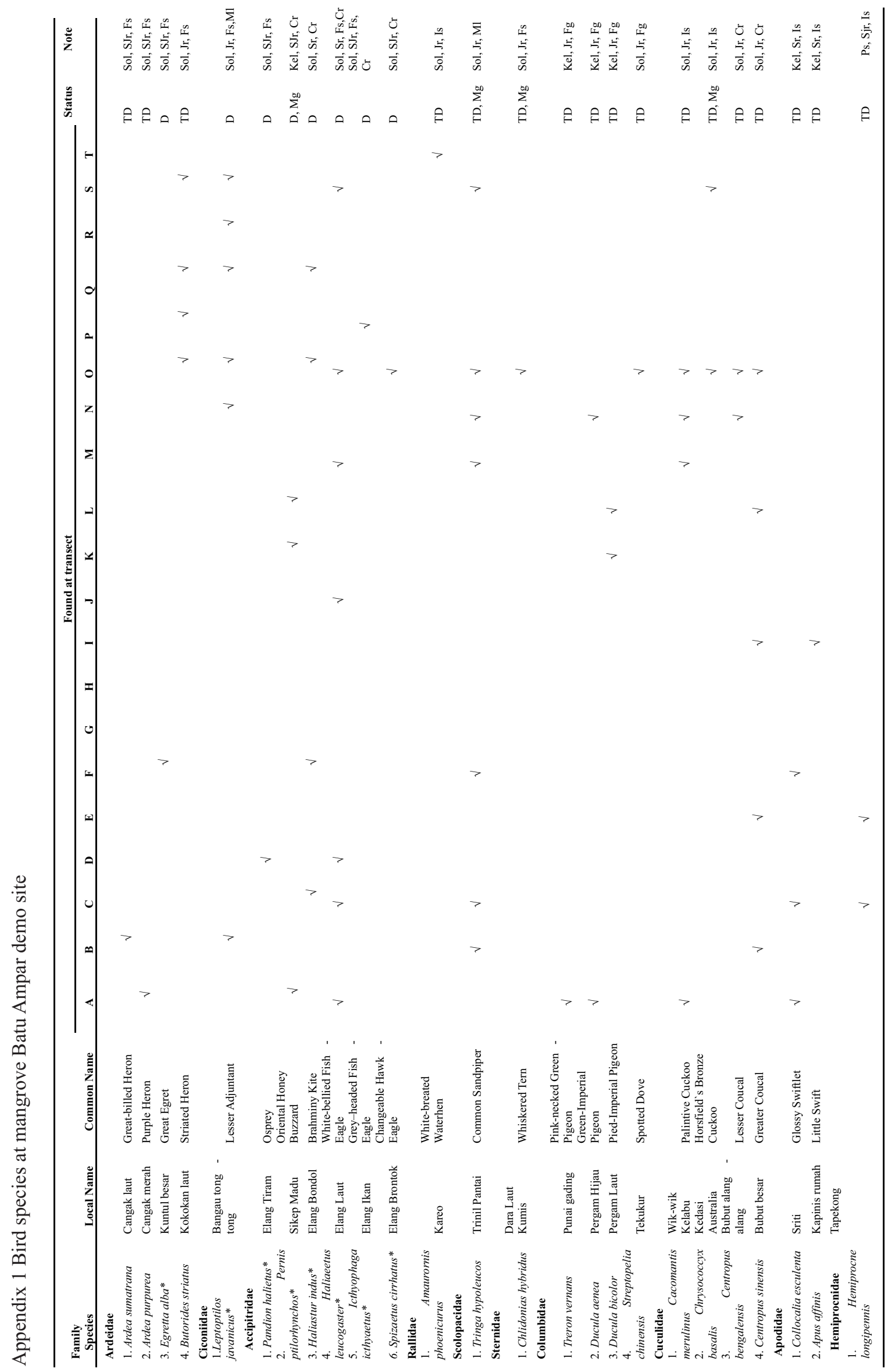




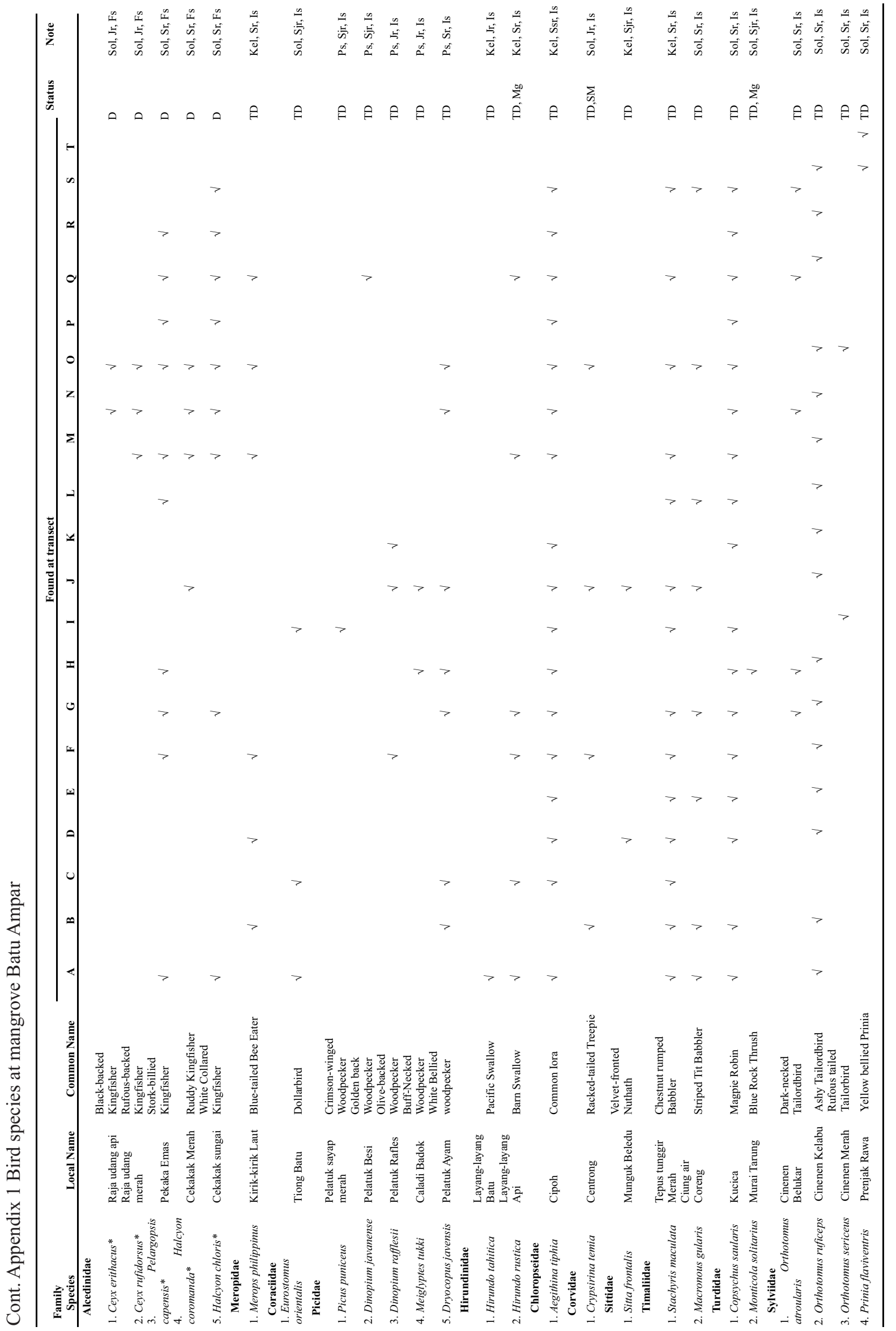




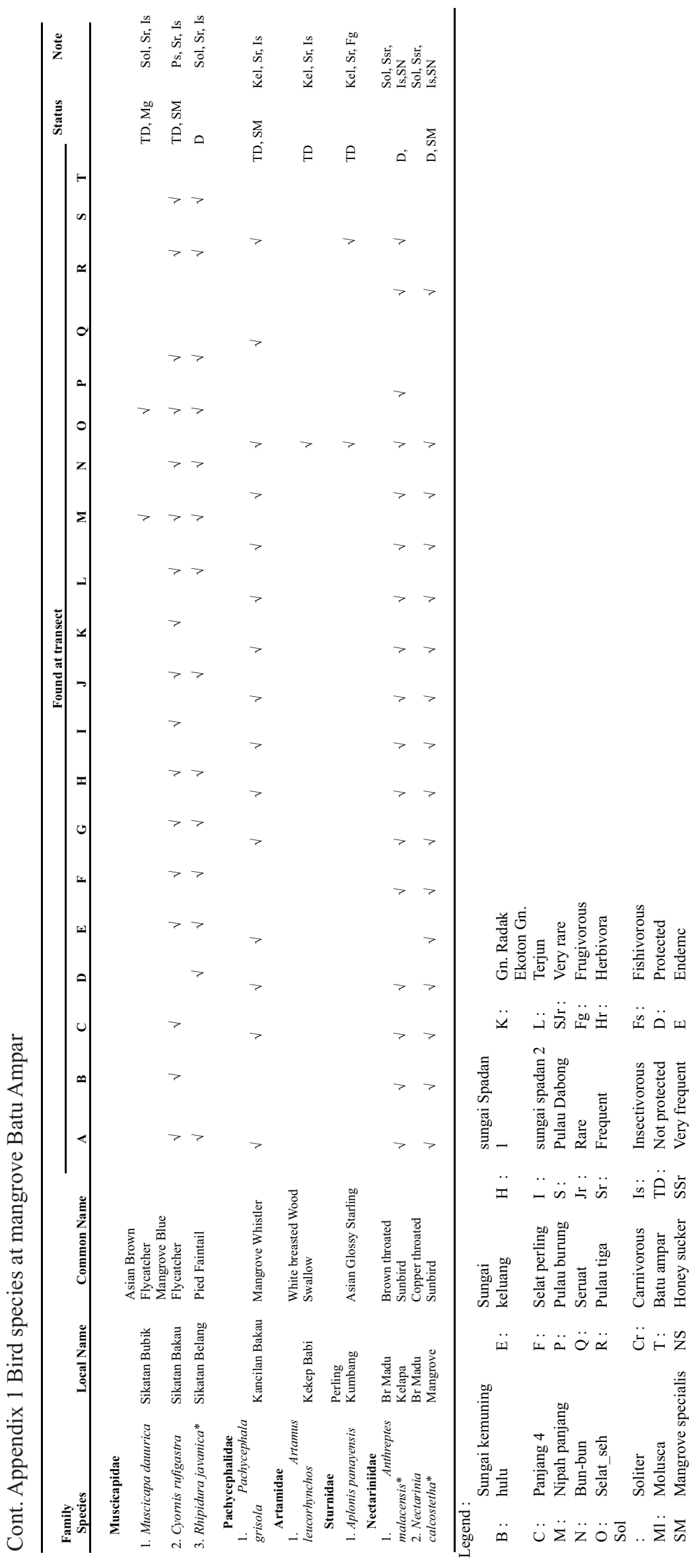




\section{Acknowledgment}

I would like to my thankfulness to Dr Nyoto Santoso was invited me to joint of this research program in Batu Ampar mangrove demo site.

\section{References}

Adil SD, Hernowo JB. 2010. Relationship between the structure and composition of tree species and the bird diversity at mangrove of the Karang-Gading and SouthEast of Langkat wildlife game reserve, North Sumatra Province. Forum Pasca Sarjana 33(1):55-65.

Aratrakorn S, Thunhikorn S, Donald PF. 2006. Changes in bird communities following conversion of lowland forest to oil palm and rubber plantations in southern Thailand. Bird Conservation International 16:71-82.

Baker J, French K, Whelan RJ. 2002. The edge effect and ecotonal species: Bird communities accross a natural edge in southeastern Australia. Ecology 83:3048-3059. http://dx.doi.org/10.1890/0012-9658(2002)083[3048: TEEAES]2.0.CO;2.

Elfidasari DJ. 2006. Diversity of water birds at Penilti mangrove forest of Pontianak Distrik. Biodiversitas 7:63-66. http://dx.doi.org/10.13057/biodiv/d070116.

Hernowo, J B. 2005. Base line study of bird at cooper mining exploration area of PT Batutua. Kharisma Permai In Wetar Island, Maluku Province. Media Konservasi X(2):59-69.

Jumilawaty E, Mardiastuti A, Budiprasetyo L, Mulyani Y. 2011. Water birds diversity in Bagan Percut Deli Serdang, North Sumatra. Media Konservasi 16(3):108-113.

Lambert FR, Collar NJ. 2002. The future for Sundaic lowland forest birds: Long- term effects of commercial logging and fragmentation. Forktail 18:127-146.

Lane VR, Miller KV, Castleberry SB, Cooper RJ, Miller DA, Wigley TB, Marsh GM, Mihako RL. 2011. Bird community reponses to a gradient of site preparation intensities in pine plantation in the coastal plain of North Carolina. Forest Ecology and Management 262:1668-1678. http://dx.doi.org/10.1016/j.foreco. 2011.07.029.
McClure HE, Husain OH. 1968. Nesting of birds in a coconutmangrove habitat in Selangor. Malayan Nature Journal 1(22):18-28.

Magurran AE. 1988. Ecological Diversity and Its Measurement. Croom Helm: London \& Sydney. http://dx.doi.org/10.1007/978-94-015-7358-0.

Mardiastuti A. 1992. Habitat and nest-site characteristic of waterbirds in Pulau Rambut Nature Reserve, Jakarta Bay, Indonesia [dissertation]. Michigan: Michigan State University.

Mueller-Dombois D, Ellenberg H. 1974. Aims and Methods of Vegetation Ecology. New York: Wiley.

Mustari A H. 1992. Water Birds Species at Mangrove of Cimanuk River Mudflat, West Java. Media Konservasi 4(5):39-46.

Nisbet ICT. 1968. The utilization of mangroves by Malaysian birds. Ibis 110:348-352. http://dx.doi.org/10.1111/j.1474919X.1968.tb00044.x.

Noske RA. 1995. The ecology of mangrove forest birds in Peninsular Malaysia. Ibis 137:250263. http://dx.doi.org/10.1111/j.1474-919X.1995.tb03247.x.

Noske RA. 1996. Abundance, zonations and foraging ecology of birds in mangroves of Darwin harbour, Northern Territory. Wildlife Research 23:443-474. http://dx.doi.org/10.1071/WR9960443.

Novarino W, Salsabila A. 2005. Type of bird diversity in the concession area PT Nusa Lease Timber Corp and PT Sestra II. Jurnal Biologica 1(9):11-21.

Sodhi NS, Johana PSC, Benjamin PYHL, Quek KC, Kara AU. 1997. Ecology of mangrove forest birds community in Singapore. The Raffles Bulletin of Zoology 45(1):1-13.

van Balen S. 1989. The terrestrial mangrove birds of Java. BIOTROP Special Publication 37:193-205.

Widodo WY, Noor R, Wirjoatmodjo S. 1996. Observation of Water Birds Indramayu-Cirebon Beach, of West Java. Media Konservasi 5(1):11-15. 